\title{
Distal Bile Duct Cancer cM1 TNM Finding v7
}

National Cancer Institute

\section{Source}

National Cancer Institute. Distal Bile Duct Cancer CM1 TNM Finding v7. NCI Thesaurus.

Code $C 90263$.

Distal bile duct cancer with distant metastasis. (from AJCC 7th Ed.) 